\title{
Small-Town Dreams Stories of Midwestern Boys Who Shaped America
}

John E. Miller

"In Small-Town Dreams John Miller ably illustrates the importance of small towns in American history and culture through a gallery of portraits of prominent figures born and raised in them-all going to show you can take the boy out of the town but not the town out of the boy."-Richard Lingeman, Senior Editor of The Nation and author of Small Town America and biographies of Theodore Dreiser and Sinclair Lewis

Includes William McKinley, William Jennings Bryan, Frederick Jackson Turner, Henry Ford, George Washington Carver, and more.

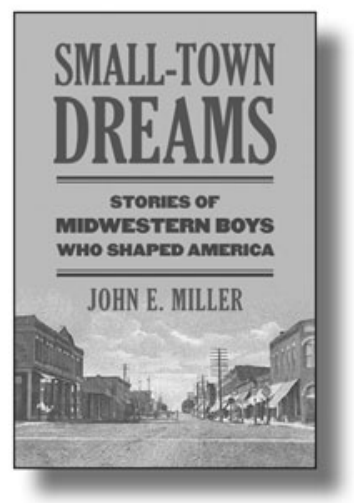

528 pages, 42 photos, 2 maps, Cloth $\$ 29.95$

\section{NEW IN PAPERBACK}

\section{Theodore Roosevelt and the American Political Tradition}

\section{Jean M. Yarbrough}

"As biography, this extraordinary book offers a rich and compelling account of TR's life. As intellectual history, it supplies the best treatment to date of TR's own political thought, situating it within the framework of the various strands of progressivism. As political theory, it explores TR's political and constitutional ideas in the light of the thought of the Founders and of Abraham Lincoln, assessing the strengths and weaknesses of TR as both a thinker and statesman. Yarbrough has pulled off the perfect intellectual trifecta."-James W. Ceaser, author of Reconstructing America

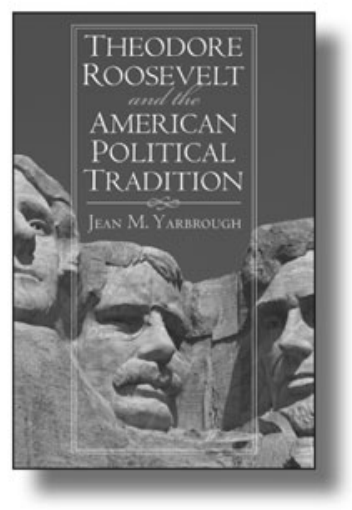
American Political Thought 352 pages, Paper $\$ 24.95$

\section{University Press of Kansas}

Phone 785-864-4155 · Fax 785-864-4586 - www.kansaspress.ku.edu 


\section{CAMBRIDGE JUURNALS}

\section{The Historical Journal}

\section{Editors}

Phil Withington, University of Sheffield, UK

Andrew Preston, University of Cambridge, UK

The Historical Journal continues to publish papers on all aspects of British, European, and world history since the fifteenth century. The best contemporary scholarship is represented. Contributions come from all parts of the world. The journal aims to publish some thirty-five articles and communications each year and to review recent historical literature, mainly in the form of historiographical reviews and review articles. The journal provides a forum for younger scholars making a distinguished debut as well as publishing the work of historians of established reputation.

Historical Journal

is available online at:

http://journals.cambridge.org/his

To subscribe contact Customer Services

\section{Americas:}

Phone +1 (845) 3537500

Fax +1 (845) 3534141

Email

subscriptions_newyork@cambridge.org

\section{Rest of world:}

Phone +44(0)1223 326070

$\mathrm{Fax}+44$ (0) 1223325150

Email journals@cambridge.org

\section{Free email alerts}

Keep up-to-date with new material - sign up at

journals.cambridge.org/register

For free online content visit: http://journals.cambridge.org 


\section{CAMBRIDGE J JUNALS}

\section{Victorian Literature and Culture \\ Editors \\ John Maynard, New York University, USA \\ Adrienne Munich, State University of New York at Stony Brook, USA}

Victorian Literature and Culture encourages high quality original work concerned with all areas of Victorian literature and culture, including music and the fine arts. The journal presents work at the cutting edge of current research, including exciting new studies in untouched subjects or new methodologies. Contributions are welcomed from internationally established scholars as well as younger members of the profession. Future Editors' topics include 'Food, Drink and the Victorians' and 'Victorian Natural History'. Review essays form a central part of the journal, and offer an authoritative view of important subjects together with a list of relevant works that serves as an up-to-date bibliography. The Works in Progress section allows the communication of parts of major works well in advance of their final publication. The Special Effects section allows publication of primary materials either previously unavailable or unknown to most readers.
Victorian Literature and Culture is available online at:

http://journals.cambridge.org/vlc

To subscribe contact Customer Services

in Cambridge:

Phone $+44(0) 1223326070$

$\mathrm{Fax}+44(0) 1223325150$

Email journals@cambridge.org

in New York:

Phone +1 (845) 3537500

$\mathrm{Fax}+1$ (845) 3534141

Email

subscriptions_newyork@cambridge.org

Free email alerts

Keep up-to-date with new material - sign up at

journals.cambridge.org/register

For free online content visit: http://journals.cambridge.org/vlc 
Over 280

leading titles online

As Complete Collection, HSS or STM

Via Cambridge Journals Online (CJO) or CJO Mobile (CJOm)

Please email:

jnlsales@cambridge.org for further info

\section{回象口 皮的 回候然}

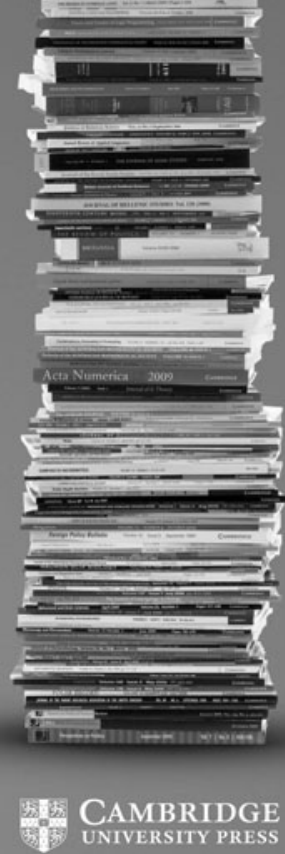




\section{JOURNAL OF THE GILDED AGE AND PROGRESSIVE ERA}

\section{SUBSCRIPTIONS AND RENEWALS}

Current subscribers: Each year during the fall, you will receive a mailed renewal notice from Cambridge University Press, as well as reminders and other information.

New institutional subscribers: Please visit http://journals.cambridge. org/jga and use the "Subscription and Prices" menu to subscribe.

New individual members: Please visit http://journals.cambridge. org/shgape to subscribe. Click the "Society for Historians of the Gilded Age and Progressive Era Membership" link, then choose the membership level you would like to purchase. (You will need to log in if you already have a CJO username or register if you do not already have one.)

Mail-in subscriptions: You may mail your subscription details to Cambridge's customer services department:

Customers in the Americas: Customers elsewhere:

Cambridge University Press Cambridge University Press

Customer Services Department Customer Services Department 100 Brook Hill Drive

West Nyack, NY 10994-2133 Shaftesbury Road

USA

Cambridge CB2 8RU

UK

\section{INSTRUCTIONS FOR ON-LINE ACCESS}

Institutional subscribers: If you are connecting from an institution with a current subscription to JGAPE, you will automatically receive access to full online content. This is enabled through the use of institutional IP address ranges and does not require a personal login. However, to use the features Cambridge Journals Online offers, including bookmarking articles, saving searches, etc., you must register on the site and select your own username and password.

Individual members: Log in to CJO (with the CJO username used to purchase your membership) and visit the journal homepage at http:// journals.cambridge.org/jga to access the journal. If you have difficulties, please contact either the CJO administrators or the journal editor. 
Society for Historians of the Gilded Age and Progressive Era

Officers and Sponsoring Organizations

President

Julie Greene

University of Maryland, College Park

Vice-President/President Elect

Lloyd Ambrosius

University of Nebraska-Lincoln

Treasurer

Gordon Bakken

California State University, Fullerton

Executive Secretary

Amy L. Wood

Illinois State University

Past Presidents

Peter Argersinger

Michael Les Benedict

Jack S. Blocker

Charles W. Calhoun

Ballard Campbell

Robert Cherny

Roger Daniels

Leslie H. Fishel, Jr.

Maureen A. Flanagan

Donna Gabaccia

Walter Nugent

Elisabeth Israels Perry

Kathryn Kish Sklar

Christopher Waldrep

\section{SHGAPE Council}

Benjamin H. Johnson

University of Wisconsin, Milwaukee

Elaine Frantz Parsons

Duquesne University

Kidada Williams

Wayne State University

Kornel Chang

Rutgers University-Newark

Rosemary Feurer

Northern Illinois University

Axel Schäfer

Keele University

Albert Broussard

Texas AEM University

Gayle Gullett

Arizona State University

Heather Cox Richardson

Boston College

Nathan Hallam

Arizona State University,

(Graduate student representative)
Illinois State University

Gregory Simpson, Dean

College of Arts \& Sciences

The Journal of the Gilded Age and Progressive Era is printed for the Society for Historians of the Gilded Age and Progressive Era by the Sheridan Press. 


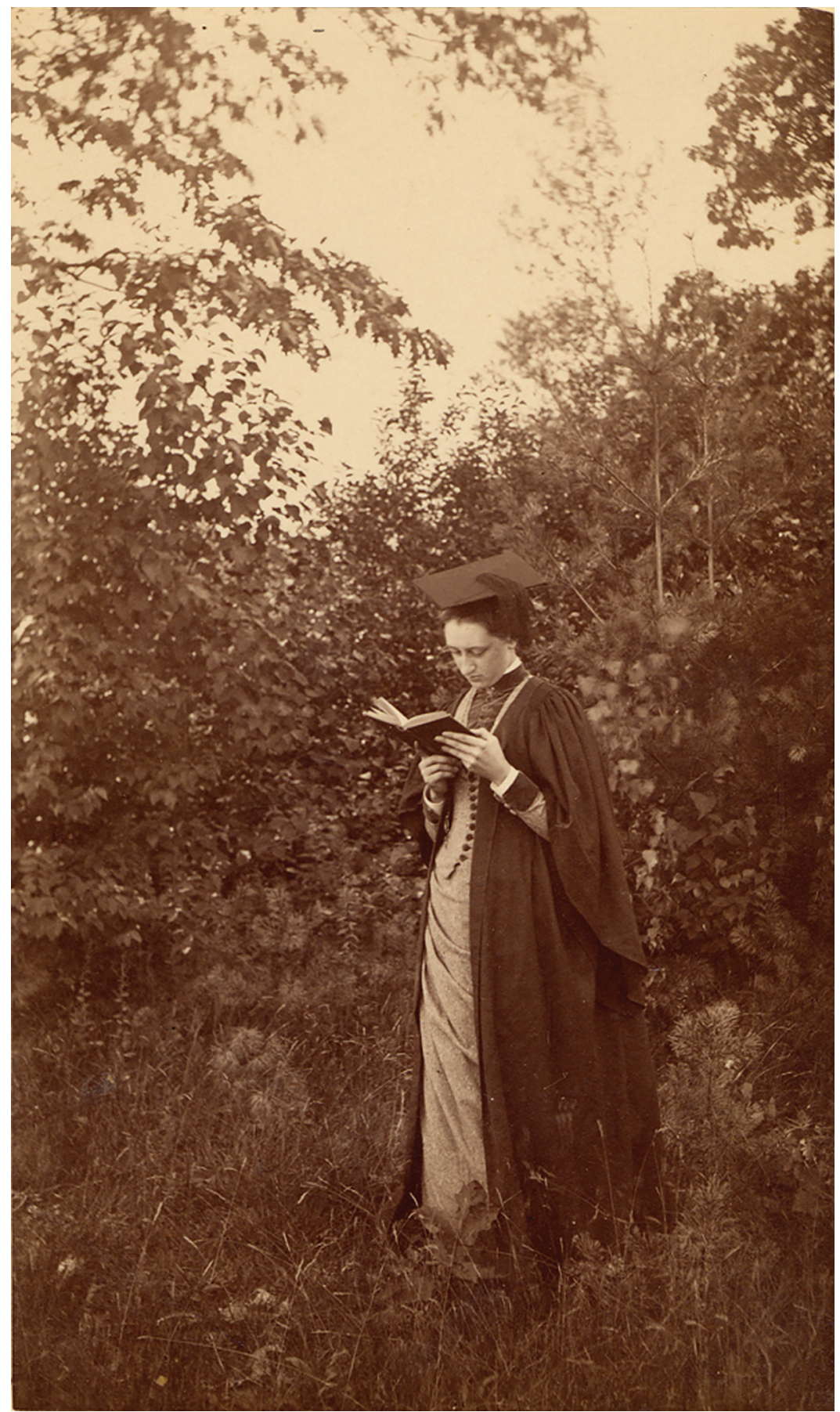

Cambridge Journals Online

For further information about this journal please

go to the journal website at:

journals.cambridge.org/jga

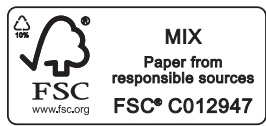

CAMBRIDGE UNIVERSITY PRESS

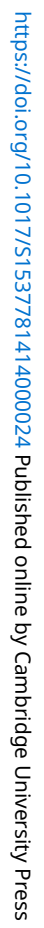

